\title{
Accounting by SMEs - Evidence from Slovenia
}

\author{
Mateja Jerman ${ }^{\mathrm{a}, 1}$ \\ ${ }^{\text {a } U n i v e r s i t y ~ o f ~ P r i m o r s k a, ~ S l o v e n i a ~}$
}

\begin{abstract}
The paper aims to investigate the characteristics of financial reporting and management accounting by Slovenian Small and Medium-sized Entities (SMEs), which represent $99.8 \%$ of all Slovene enterprises. The paper examines the most important legal bases for external financial reporting of SMEs, rules in national accounting standards and their close linkage with taxation. The paper highlights how Slovenia adopted the relevant European Union (EU) Directives and emphasizes the particularities of the Slovenian environment that demonstrate diversity at the international level. The paper raises issues concerning lenient requirements on accounting practitioners' qualifications and a lack of supervision of financial statements. We then provide a literature review of relevant studies in the field of financial and management accounting. The financial accounting literature seems to be more developed than that of management accounting. Studies reviewed in this paper mainly focused on the link between financial accounting and taxation, indicating that the use of accounting discretion is motivated by the effort to minimize taxation.
\end{abstract}

Keywords: SMEs, financial reporting, financial accounting, management accounting, Slovenia

\section{JEL codes: $M 41$}

\section{Introduction}

The Slovenian economy is influenced by the continental European accounting system in which capital is mainly provided by the banking sector, law provides detailed accounting rules, financial accounting is closely connected with taxation, the primary users of financial statements are creditors and tax authorities, and there

${ }^{1}$ Corresponding author: University of Primorska, Faculty of Management, Cankarjeva 5, 6101 Koper, Slovenia; tel. +386 561020 48; fax + 386561020 15; E-mail address: mateja.jerman@fm-kp.si 
is a tendency towards limiting the extent of disclosures (Haller \& Walton, 2003). Slovenia is interesting in this regard for several reasons. Since the country became independent in 1991 the business environment has been characterized by the privatization process (ownership transformation), followed by internationalization and the access of Slovenia into the EU (2004). All these circumstances have affected the development of the corporate reporting system.

Small and medium-sized entities (SMEs) are essential to the Slovenian economy. They represent $99.8 \%$ of all national enterprises, their share in employment amounts to $70 \%$ and $66.8 \%$ of total revenues (SI-STAT, 2016). Thus, it is important how they report their financial information, what kind of information they provide to external users of financial statements, and how well they manage their accounting for purposes of internal reporting.

The paper examines legal provisions and rules in accounting standards concerning financial reporting of SMEs in Slovenia. A comparative analysis of national rules with EU Directives and full International Financial Reporting Standards (IFRS)/IFRS for SMEs highlights how Slovenia adopted the relevant EU Directives and emphasizes the particularities of the Slovene regulatory framework. The paper also provides a literature review of evidence from financial and management accounting studies made on samples of Slovenian SMEs.

Findings show that recent changes of the Companies Act and national accounting standards simplified the corporate reporting of small and especially microenterprises. Despite the fact that the Slovenian Companies Act states that Slovenian Accounting Standards (SAS) shall not be contrary to IFRS, the comparative analysis performed in the paper shows that there are indeed certain differences between them. The paper also raises issues concerning lenient requirements for accounting practitioner qualifications and a lack of supervision of financial statements. The literature review of relevant studies from the field of financial and management accounting shows characteristics and particularities of the accounting of SMEs in Slovenia.

The present paper contributes to the literature in emerging economies (for more details see for example Garrod \& Turk, 1995; Novak, 2008; Hopper et al., 2009; Odar et al., 2015; Novak \& Valentinčič, 2017) by examining the development of accounting in an emerging country. Particularities of the Slovenian environment will illustrate international diversity and as such could be of interest to an international readership. Many Slovenian studies have been written in the Slovenian language and as such unavailable to the international public (e.g. Kavčič et al., 1998; Kavčič et al., 2003; Kavčič et al., 2004a; Kavčič et al., 2004b; Odar et al., 2009; Kavčič et al., 2010; Prusnik, 2013; Kavčič et al., 2013; Kavčič et al., 2014). The review of the studies will enable international audience to learn about the characteristics of accounting in Slovenia. 
The structure of the paper is as follows. In the first section, we illustrate the content of annual reports, the required audit of financial accounts, the relationship between financial statements for financial reporting and tax purposes, professional rules in accounting standards and their key changes and the accounting profession in Slovenia. The second section concludes with a presentation of the relevant studies from financial accounting by SMEs from Slovenia. The third section is devoted to reviewing the results of studies in management accounting from Slovenia. The conclusions along with suggestions for improvements are presented in the final section.

\section{Characteristics of external financial reporting of Slovenian SMEs}

In 2015 , there were in total 191,963 active enterprises, employing 837,454 persons and recording $€ 95.299$ billion in revenues (SORS, 2016). Most of these enterprises employed one person (73.5\%), followed by micro-enterprises with 2-9 employees $(21.5 \%)$ (SI-STAT, 2016). The importance of SMEs for the Slovenian economy is presented more in detail in table 1 below.

Table 1. Importance of SMEs for the Slovenian economy

\begin{tabular}{lcccc}
\hline & $\begin{array}{c}\text { Micro } \\
\text { enterprises }\end{array}$ & $\begin{array}{c}\text { Small } \\
\text { enterprises }\end{array}$ & $\begin{array}{c}\text { Medium-sized } \\
\text { enterprises }\end{array}$ & Total \\
\hline $\begin{array}{l}\% \text { of total } \\
\text { enterprises }\end{array}$ & $95.1 \%$ & $3.7 \%$ & $1 \%$ & $99.8 \%$ \\
$\begin{array}{l}\% \text { of total } \\
\text { employment }\end{array}$ & $29.6 \%$ & $16.8 \%$ & $23.6 \%$ & $70 \%$ \\
$\begin{array}{l}\% \text { of total } \\
\text { revenues }\end{array}$ & $20.7 \%$ & $20 \%$ & $26.1 \%$ & $66.8 \%$ \\
\hline
\end{tabular}

Source: SI-STAT, 2016

Requirements regarding external financial reporting depend not only upon enterprises' size but also by their legal form. In 2015, among all Slovenian enterprises $45.7 \%$ were legal entities and $54.3 \%$ natural persons. The most numerous of all were "samostojni podjetniki [sole traders]", whose share was $48.0 \%$. The majority of legal entities are "družbe $\mathrm{z}$ omejeno odgovornostjo [limited liability companies]" (SORS, 2016). Taken together, sole traders and limited liability companies total $79.8 \%$ of Slovenian enterprises.

Slovenian companies take one of the following legal forms (Companies Act, 2006): a) "osebna družba [partnership]": "družba z neomejeno odgovornostjo [unlimited company]" or "komanditna družba [limited partnership]"; or b) "kapitalska družba [company limited by shares]": "družba z omejeno odgovornostjo - d.o.o. [limited liability company]", "delniška družba - d.d. [public limited company]", 
"komanditna delniška družba [partnership limited by shares]" or "evropska delniška družba [European public limited-liability company]".

The legal basis for external financial reporting is provided by the Companies Act (2006). It delineates general rules on accounting, auditing, public announcement of annual reports, the content of the annual report and the general rules concerning the valuation of items in financial statements. The Companies Act refers to accounting standards, requiring that companies and entrepreneurs keep books of accounts and complete them annually in accordance with the act and the SAS or IFRS.

Companies whose securities are traded on one of the organized securities markets in the Member States of the European Community and are subject to consolidation have to report in accordance with IFRS. IFRS is applied by banks, insurance companies, and other companies if the general meeting so decides (in this case, the enterprise has to use IFRS for at least five years). From 2015 IFRS are also used for consolidated financial statements. Medium-sized and small companies are not obliged to use IFRS, unless they are classified among the previously mentioned groups of companies. Most of the Slovene SMEs report in accordance with SAS. SAS 2016 is effective since 1 January 2016. This is the third revised version of SAS. The first SAS were adopted in 1993, followed by SAS 2002, SAS 2006 and SAS 2016.

In accordance with the Companies Act, companies must prepare the annual report for each financial year within three months after the end of the financial year (Companies Act, 2006). The annual report must be submitted to the Agency of the Republic of Slovenia for Public Legal Records and Related Services (AJPES). AJPES must publish an annual report in computerized form on its website (Companies Act, 2006). The obligation of annual report publication did not change after the implementation of EU Directive 2013/34. Slovenia has not exempted from mandatory reporting the smallest enterprises.

Entrepreneurs who are taxed on the basis of profit, taking into account "normirani odhodki [flat-rate expenses]", are not obliged to submit annual reports for publication (Companies Act, 2006). More details about the system of flat-rate expenses are presented in section 2.3.

Annual reports of medium-sized "kapitalska družba [company limited by shares]" (most common are: "družba z omejeno odgovornostjo [limited liability company]", and "delniška družba [public limited company]") and "dvojna družba [double partnership]" must include the auditor's report since they have to be audited. The annual reports of these companies must be transmitted to AJPES within eight months after the end of the financial year for the purpose of public announcement. 


\subsection{The content of the annual report}

The content of annual reports of Slovenian enterprises depends upon their size and legal form. Annual financial statements of small "kapitalska družba [company limited by shares]" whose securities are not traded on a regulated market are composed of minimum required statements defined by the Directive 2013/34 (i.e. a balance sheet, income statement and notes to the financial statements). As permitted by the Directive 2013/34 Slovenia requires more numerous financial statements for enterprises other than small enterprises. In accordance with Slovenian Companies Act medium-sized "kapitalska družba [company limited by shares]" and "dvojna družba [double partnership]" have to prepare (Companies Act, 2006): a balance sheet, income statement, cash flow statement, statement of changes in equity, notes to the financial statements and the management report. They must also draw up the statement of comprehensive income or other comprehensive income. The statement of comprehensive income may be presented as a separate statement or as part of the income statement.

In Slovenia, the number of required annual financial statements differs between companies and entrepreneurs of the same size. In accordance with SAS (SAS 2016, 30.1) medium-sized entrepreneurs have to prepare all previously mentioned financial statements as medium-sized "kapitalska družba [company limited by shares]", with the exception of statement of comprehensive income. The latter is obligatory only for companies which are audited. However, on December 31, 2016 there were no active large entrepreneurs and only one medium-sized (GVIN, 2017).

On the other hand an entrepreneur whose business meets the criteria for a small or micro-company, has to compile (Companies Act, 2006): a balance sheet and income statement. Entrepreneurs are not required to prepare notes to financial statements. Moreover, entrepreneurs are not required to keep books of accounts and draw up the annual report, if he/she is taxed on the basis of the profit, taking into account flatrate expenses (Companies Act, 2006). On the other hand, companies (legal entities) which are taxed on the basis of this system do not have any simplifications in terms of keeping books of accounts.

Given the structure of Slovenian enterprises' sizes and legal forms, the majority of Slovenian enterprises for the purpose of external financial reporting prepare only a balance sheet and income statement. Moreover, many entrepreneurs do not compile annual reports for external reporting purpose (because they have the option not to do so, if they are taxed by taking account of flat-rate expenses). The latest data show that currently approximately $31 \%$ of natural persons engaged in business use this kind of option (Delo, 2016).

The structure of the balance sheet and income statement for external financial reporting purposes is delineated by the Companies Act. The breakdown is different 
for large, medium-sized and small companies. The breakdown does not differ between small and micro companies. As permitted by the Directive 2013/34 Slovenian small and micro-entities are required to draw up abridged financial statements compared with medium-sized entities. Differences in the layout of financial statements are greater among medium-sized and small/micro companies, in comparison to the differences between legal entities and natural persons engaged in business of the same size. SAS additionally simplifies the layout of financial statements for external reporting of the smallest entrepreneurs (i.e. microentrepreneurs).

In Slovenia, enterprises use the vertical layout of the balance sheet (Directive 2013/34 allows two options), while enterprises have the option to choose between two layouts of income statement permitted by the Directive (i.e. by nature of expense or by function of expense). SAS suggests the second type of layout. The exception are micro-entrepreneurs who have to compile the income statement presenting expenses by their nature (SAS 2016, 30.4). SAS additionally defines the structure of the cash flow statement and the statement of changes in equity.

An important difference between the medium-sized and small (micro) enterprises in the volume of reported information refers to the volume of the notes to the financial statements. SAS lists the required disclosures for enterprises that are committed to audit (including medium-sized enterprises). Small and micro-enterprises are not supposed to provide disclosures required by SAS but must prepare only information required by the Companies Act which are in line with notes required by the Directive 2013/34 for all undertakings. This information is most frequently the predominant part of all notes provided by Slovenian small businesses (in addition to the information in the financial statements).

In accordance with the possibilities given by the Directive 2013/34 regarding exceptions for micro-undertakings the Companies Act introduced a special regimen for micro-companies in 2015. Micro "kapitalska družba [company limited by shares]" that do not measure assets in accordance with the principle of fair value, but in accordance with the principle of historical cost, are not obliged to compile all notes that are required by the Companies Act for small companies, but must disclose only a part of them (the requirements are in conformity with those listed in the Directive). The required information for this kind of micro-entities is the following (Companies Act, 2006):

1. the total amount of contingent financial liabilities which are not included in the balance sheet,

2. if that information is important for assessing the financial position of the company, the amount of any obligations that are secured (lien, etc.),

3. advances and loans made by the company or its subsidiaries to members of management, supervisory board members, other employees of the company and contract employees not subject to the tariff part of the collective agreement,

4. if a company has own shares during the financial year. 
Slovenia exempted small and micro-enterprises from the obligation to prepare management reports. A management report of medium-sized companies and medium-sized entrepreneurs, must include at least (Companies Act, 2006): a fair presentation of the development and results of company's operations and its financial position, including a description of the principal risks and uncertainties to which the company is exposed. Fair view should be a balanced and comprehensive analysis of the development and performance of the company and its financial position, which corresponds to the extent and complexity of its operations. The analysis must, to the extent necessary for understanding the development and performance of the company and its financial position, contain the financial, and other indicators, including information related to environmental protection and employees.

In the management report companies must also show all major business events that occurred after the end of the financial year. If this is important the management report shall also include the objectives and measures of financial risk management, and the company's exposure to price, credit, liquidity risks and risks related to cash flow (Companies Act, 2006).

Companies subject to audit (including medium-sized companies) must include in their annual reports a corporate governance statement which has to include a reference to the corporate governance code, a description of the main features of internal controls and risk management. Contents of the management report are in a large part in conformity with EU Directives.

\subsection{Audit of annual reports}

An audit of annual reports is required for large and medium-sized companies and those reports of small companies whose securities are traded on a regulated market. Recently the Companies Act introduced the "preiskava računovodskih izkazov [examination of financial statements]" for certain small enterprises. Previously, small and micro-enterprises were not forced to inspect their financial statements. From and including 2016 onwards, the auditor should carry out an examination of the annual financial statements for those small "kapitalska družba [company limited by shares]" that measure property and plant assets at revalued values, investment property at fair value, or have in their accounts financial instruments for which no quoted price on regulated markets is available, including financial derivatives. The examination of the financial statements must be done within six months after the end of the financial year.

Since neither the Companies Act nor SAS require that the fair value measurement has to be performed by a certified appraiser, we believe that this type of examination has enhanced the quality of financial data, as previously this type of measurements in small "kapitalska družba [company limited by shares]", were not subject to verification. 
In Slovenia, a licence to carry out the tasks of a certified auditor is issued by the "Slovenski inštitut za revizijo [Slovenian Institute of Auditors]". Compulsory auditing (defined by the Companies Act) can be performed only by auditors who meet the conditions laid down by the EU Directive (adequate educational qualifications, examination of professional competence). In accordance with the current Slovene Auditing Act a person shall also have a minimum of five years of work experience (the Directive 2014/56 requires a minimum of 3 years), with a minimum of three years of experience in auditing in the six years prior to submission of the application for the issue of the license (Auditing Act, 2008, Article 48). A person who had a license for carrying out the tasks of a certified auditor withdrawn in the past lost the license permanently. In addition to these conditions an individual must have a high level of proficiency in the Slovenian language. The license to carry out the tasks of a certified auditor is valid two years from the date of issue. The validity of the license can be renewed every two years at the holder's request, provided that he/she undergoes additional professional training in accordance with applicable rules (Auditing Act, 2008, Article 48). At the end of 2016 there were 52 active auditing firms in Slovenia (The Slovenian Institute of Auditors, 2016). Supervision of the quality of auditing is performed by the Institute of Auditors and the Agency for the Public Oversight of Auditing in accordance with their competencies pursuant to the Auditing Act (Auditing Act, 2008, Article 6). Due to the adoption of Directive 2014/56 and Regulation 537/2014, in 2015 in Slovenia began the process of drafting the Auditing Act 3. The latter will transpose the provisions of the aforementioned EU legislation. The process remains ongoing.

For the year 2015, 155,842 annual reports for the purpose of public announcement were submitted to AJPES. Of these, only 1,671 were audited (AJPES, 2016), which represents $1 \%$ of total annual reports. If a company is not listed and is not a corporation subject to external audit, then there is no other direct official financial reporting enforcement authority apart from the tax authorities.

\subsection{Connection between financial accounting and taxation}

In accordance with the "Zakon o davku od dohodkov pravnih oseb - ZDDPO-2 [Corporate Income Tax Act]" (2006) the determination of profit for tax purposes is grounded on recognized income and expenses found in the income statement prepared in accordance with established accounting standards. The income tax rate in 2016 was $17 \%$, in 2017 it rose to $19 \%$.

Taxable income is based on commercial income from the individual entity income statement, which is for tax purposes modified according to specific tax rules. Law on Corporate Income Tax defines certain categories which are recorded differently than in accounting standards. In addition to the adjustments of certain expenses and revenues the Law on Corporate Income Tax allows "davčne olajšave [tax relief]". These allowable deductions from the tax base are (Law on Corporate Income Tax, 
2006): for investment in research and development; for investment in equipment and intangible assets; employment; for voluntary supplementary pension insurance; for grants; and on employment and investment in certain regions.

The alternative to the calculation of taxable income based on commercial income is the system of flat-rate expenses. Some taxpayers, if they fulfill conditions defined by the law, can determine the tax base by taking account of actual revenues reduced by $80 \%$ of flat-rate expenses (calculated as $80 \%$ of recorded revenues). Taxable income is thus equal to $20 \%$ of recorded revenues. Such taxpayers are not able to use tax reliefs and expenses actually incurred.

Natural persons engaged in business more commonly use (approximately $31 \%$ ) the system of flat-rate expenses in comparison with legal persons. The latest data show that in 2015 only approximately 1\% of legal persons chose this option (Delo, 2016).

Among the legal entities and natural persons engaged in business, there is a difference in books of accounts if their income tax base is determined by taking account of flat-rate expenses. For legal persons, this status does not affect the requirements regarding bookkeeping and reporting. On the other hand, natural persons engaged in business with such a status have very little obligations regarding financial reporting. They are not required to keep records of expenses and the costs of their operations. To determine the tax base they are not required to keep books of accounts, but only the required tax evidence. For many entrepreneurs, this law simplified their obligation of mandatory financial reporting and keeping books of accounts. These kinds of entrepreneurs are not required to submit financial statements for public announcement.

For natural persons engaged in business, the taxation of profits is determined by the Personal Income Tax Act (2006) by: 1) taking into account actual revenues and expenses, or 2) by taking account of flat-rate expenses. Profit is in their case taxed progressively. Currently, the scale of five grades of tax rates from $16 \%$ to $50 \%$ is in use. The exception are persons who qualify and opt for taxation on the basis of flatrate expenses who apply a tax rate of $20 \%$.

In addition to "davčne olajšave [tax relief]" that may be taken into account by legal persons, natural persons engaged in business can also take into account the general allowance, deduction(s) for dependents and relief for voluntary supplementary pension insurance premiums.

Slovenia is characterized by a close relationship between financial accounting and taxation. Income statements for tax purposes result from the income statements prepared for the purpose of external financial reporting. Tax authorities are an indirect general enforcement authority for accounting standards (Jerman \& Novak, 2014). In 2015, there were 191,863 companies actively operating. At the same time, 
as of December 31st, 2015 the number of tax inspectors in the Financial Administration of the Republic of Slovenia was 434 (Ministry of Public Administration, 2016). Clearly, the number of tax inspectors is relatively low. As a result, the number and extent of inspections is rather limited. This is the only form of control for the majority of small and micro organizations.

\subsection{Accounting rules in "Slovenski računovodski standardi - SRS [Slovenian Accounting Standards - SAS]"}

The first SAS were issued in 1993, and began to be used on 1 January 1994. The first revision followed in 2001 with the issuance of the SAS 2002. The revised standards were striving for the use of fair value principle, particularly with regard to the presentation of assets and liabilities. Since Slovenia joined the European Union, the European Directives had to be introduced into Slovenian law. For this reason the revised SAS were published in 2005 (for more details about the historical development of SAS see Garrod \& Turk, 1995; Novak, 2008; Jerman \& Novak, 2014; Novak \& Valentinčič, 2017). The last revision followed in 2015, when SAS 2016 were issued (in force from 1 January 2016). SAS 2016 transferred into the Slovenian law contents of the new accounting directive 2013/34.

SAS 2016 were adapted in particular for preparation of separate financial statements of medium, small and micro entities. In addition to changes that were made as a consequence of EU law transfer into SAS, other changes were completed in the direction of accounting simplification.

The current SAS 2016, unlike previous versions, contain only the rules of financial accounting and reporting, not the solutions for internal reporting (previously an integral part of the standards). SAS 2016 are complemented by so-called »Good accounting practice rules « (Pravila skrbnega računovodenja - PSR), which contain solutions for: bookkeeping, budgeting, financial control, financial analysis, financial reporting and consolidation. The PSR are not mandatory, since they are only an addition to the SAS. A large part of the current PSR was in the earlier version of the SAS included in separate sections in standards (SAS 20-23 and SAS 28-30). The application of these SAS was not obligatory, but was recommended primarily in the case of internal reporting. These SAS were called accounting standards for mere formal reasons (SAS, 2006).

SAS 2016 are divided into the following sections: Introduction to SAS and the framework of the SAS, SAS considering the accounting of economic categories that are observed in accounting (Standards I), standards of external financial reporting (Standards II) and standards that define accounting solutions for organization of specific activities (Standards III). The SAS framework contains the following chapters (SAS 2016, Introduction):

- Basic accounting assumptions and qualitative characteristics of accounting. 
- Recognition of economic categories in financial statements and accounting records.

- Measurement of economic categories in financial statements and accounting records.

- The revaluation of economic categories in financial statements and accounting records.

- Changes in accounting estimates, changes in accounting policies and corrections of errors.

- Business combinations (mergers).

- Deferred tax assets and deferred tax liabilities.

- Joint Arrangements.

- A group of organizations.

The central part of the standards contains disclosure requirements of individual financial categories. These disclosures are required for organizations whose annual reports shall be examined by an auditor (in this set, medium-sized enterprises). Small and micro organizations, must reveal only statutory information and data.

Standards I deal with professional rules for the accounting of certain types of assets and liabilities, costs, expenses and revenues. The standards eliminated accounting solutions related to consolidation. In accordance with the amendments of the Companies Act from the year 2015, the consolidated financial statements are now prepared using IFRS (previously companies could use SAS or IFRS). The group of Standards II includes the presentation of the balance sheet, income statement, cash flow statement and statement of changes in equity for external reporting purposes.

What is new in SAS 2016 is that the rules for recognizing, measuring, evaluation and disclosure were set out for all entities, irrespective of legal status and form. The set of standards III deals only with the particularities of accounting in various entities. Previously they also contained specific rules regarding the recognition, derecognition, measurement and evaluation of economic categories.

Unlike SAS 2006, SAS 2016 no longer refers to IFRS. The SAS 2016 are now completely independent standards. To this end, the authors of SAS complemented some SAS solutions with those from IFRS; therefore, SAS does not rely on them anymore. SAS 2016 is based on the provisions of the Directive 2013/34 and those of the Slovenian Companies Act. Where the Directive 2013/34 or Companies Act does not provide otherwise, SAS 2016 follows the fundamental accounting rules of IFRS.

Although the Slovenian Companies Act (2006) states that SAS shall transpose the content of Directive 2013/34 and their concept must not be contrary to IFRS, there are certain differences between SAS and IFRS. Key differences between SAS and IFRS in terms of recognition, measurement and valuation are presented in more detail in the following section. 


\subsection{Changes of SAS 2016 and their comparison with IFRS and IFRS for SMEs}

SAS 2016 introduced some significant changes in terms of recognition, measurement and valuation of economic categories. The most important are as follow:

- In the case of property, plant and equipment (PP\&E), SAS 2016 in contrary to SAS 2006 does not permit revaluations of equipment.

- There were also some changes in relation to the revaluation surplus. In accordance with SAS 2006 a revaluation which affected the value of equity was presented in the balance sheet in one single item. The layout of the balance sheet in accordance with SAS 2016 changed. Currently, two separate items are presented: i.e. revaluation reserve (showing revaluation of PP\&E) and fair value reserve (showing effects of all other revaluations, especially those of financial assets).

- SAS 2016 allows only one possible reversal of the revaluation reserve. The revaluation reserve is reversed to retained earnings when the revalued recognition of PP\&E is derecognized. In accordance with the EU Directive 2013/34 no part of the revaluation reserve may be distributed, either directly or indirectly, unless it represents a gain actually realized. Previous SAS 2006 allowed that some of the surplus could be transferred as the asset was used by the entity.

- SAS 2016 does not allow anymore revaluations of intangible assets. Previous SAS allowed intangibles to be revalued to fair value if they had an active market (SAS 2006, 2.30).

- In SAS 2016 goodwill is treated as an intangible asset with a definite useful life. When the useful life cannot be reliably determined, goodwill is amortized using the straight-line method over five years (SAS 2016, 2.26). Previously the goodwill could be classified as an intangible asset with an indefinite useful live. In accordance with SAS 2006 goodwill was not subject to amortization, only tested for impairment (SAS 2006, 2.26).

- Changes to SAS 2016 relate also to the field of financial investments. The revised standards contain more detailed provisions about the methods of identifying impairments and the rules of accounting in relation to hedging.

SAS 2016 introduced certain simplifications for micro organizations. Micro entities that are not subject to audit, may decide that the deferred tax will not be accounted for (SAS 2016, Introduction). Simplification also applies to provisions for jubilee awards and severance pay upon retirement. Even these micro-entities are not obliged to account for. In accordance with SAS 2006 deferred taxes, provisions for jubilee awards and severance pay upon retirement were not recorded if this kind of information was not material. Many small companies did not present them. Since SAS 2016 is in use small companies do not have this option anymore. For many small companies this represents an additional administrative burden. 
SAS is in a large part in conformity with IFRS. However, there are some differences between them. In relation to the aforementioned changes of SAS 2016, we present the most important differences between rules in SAS 2016 and those of IFRS and IFRS for SMEs (table 2).

In accordance with IFRS/IFRS for SMEs all items of PP\&E can be revalued. On the other hand, users of SAS 2016 cannot apply the revaluation model for equipment. Reversals of the revaluation reserve differ between SAS 2016 and full IFRS, while IFRS for SMEs do not provide detailed guidance. SAS 2016 and IFRS for SMEs do not permit the revaluation of intangibles, while IFRS permits revaluations if there is an active market for these assets. Goodwill is in accordance with SAS 2016 amortized (and tested for impairment) in its useful life. If the useful life cannot be determined, it is written off over the period of five years. Similar are the rules in IFRS for SMEs with the only difference that goodwill has to be written off over the period of ten years if its useful life cannot be determined. On the other hand full IFRS require goodwill to be tested for impairment. The comparative analysis of selected accounting rules shows that SAS 2016 is more in conformity with IFRS for SMEs than full IFRS.

Table 2. Comparative analysis of selected accounting rules in SAS 2016 with those of IFRS and IFRS for SMEs

\begin{tabular}{|c|c|c|c|}
\hline $\begin{array}{c}\text { Rules in } \\
\text { accounting } \\
\text { standards }\end{array}$ & SAS 2016 & IFRS & IFRS for SMEs \\
\hline $\begin{array}{l}\text { Revaluation of } \\
\text { PP\&E }\end{array}$ & $\begin{array}{l}\text { Equipment cannot be } \\
\text { revalued }\end{array}$ & $\begin{array}{l}\text { All items of PP\&E can be } \\
\text { revalued }\end{array}$ & $\begin{array}{l}\text { All items of PP\&E } \\
\text { can be revalued }\end{array}$ \\
\hline $\begin{array}{l}\text { Reversal of the } \\
\text { revaluation } \\
\text { reserve }\end{array}$ & $\begin{array}{l}\text { One option - when the } \\
\text { revalued recognition of } \\
\mathrm{PP} \& \mathrm{E} \text { is derecognized }\end{array}$ & $\begin{array}{l}\text { Two options - a) the } \\
\text { surplus can be transferred } \\
\text { as the asset is used by the } \\
\text { entity or b) is transferred } \\
\text { when the revalued } \\
\text { recognition of PP\&E is } \\
\text { derecognized }\end{array}$ & $\begin{array}{l}\text { Detailed guidance not } \\
\text { provided }\end{array}$ \\
\hline $\begin{array}{l}\text { Revaluation of } \\
\text { intangible } \\
\text { assets (other } \\
\text { than goodwill) }\end{array}$ & Not permitted & Permitted & Not permitted \\
\hline Goodwill & $\begin{array}{l}\text { Amortized in its useful } \\
\text { life. If the useful life } \\
\text { cannot be determined, } \\
\text { it is written off over } \\
\text { the period of five years }\end{array}$ & $\begin{array}{l}\text { Goodwill is tested for } \\
\text { impairment }\end{array}$ & $\begin{array}{l}\text { Amortized in its } \\
\text { useful life. If the } \\
\text { useful life cannot be } \\
\text { determined, it is } \\
\text { written off over the } \\
\text { period of ten years }\end{array}$ \\
\hline
\end{tabular}


Moreover, IFRS and IFRS for SMEs do not prescribe the form of financial statements for external financial reporting. Slovene Companies Act and SAS 2016 precisely prescribe the form of the balance sheet and income statements for external reporting purposes (SAS additionally defines the structure of the cash flow statement and the statement of changes in equity). The format is exactly prescribed for different sizes of organizations.

We expect that the extent of differences between SAS and IFRS will increase in time, since the frequency of IFRS changes is greater than those of SAS.

\subsection{Accounting profession in Slovenia}

Due to particularities regarding the regulation of the accounting profession in Slovenia, we also present the characteristics related to the profession of accountants in this emerging economy. Accounting practitioners are not required to have any professional qualification nor a professional certificate. There are no requirements for mandatory registration. Professional certificate can be obtained on a voluntary basis. The Slovenian Institute of Auditors performs the training process for "preizkušeni računovodja [qualified accountant]", while the Chamber of Commerce and Industry of Slovenia offers the title "Strokovni vodja računovodskega servisa [Expert Manager of (external) Accounting Services]".

The bookkeeping process and the preparation of annual reports can be performed by accountants who are employed in the organization (internal accountants) or by external firms providing accounting services. For the latter, Slovenian law does not require any particular criteria that should be met for conducting business. As stated by Slapničar et al. (2013), practitioners working in accounting firms have various educational backgrounds and experiences. The latest data show that in 2015 there were 3,661 companies operating as accounting firms employing 4,095 employees (Chamber of Commerce and Industry of Slovenia, 2016).

Typically, large and medium-sized companies have internal accountants (they work in an internal accounting department), while many small companies and especially micro-companies often use external accounting service providers. The number of firms operating as accounting service providers in Slovenia is relatively high.

The legislature should consider establishing minimum professional qualifications for accountants in Slovenia and their mandatory registration, since there are currently no minimum requirements and anyone can pursue this profession.

\subsection{Review of research of Slovenian SMEs from the field of financial accounting}

Little research has been done in the field of financial accounting involving Slovenian SMEs. To date research is mainly focused on large companies, especially those whose securities are traded on a regulated market. The reason for this is probably the 
fact that small and micro-enterprises disclose a limited extent of information to external users of financial statements and thus their analysis is rather difficult. Another simple reason for the limited number of studies on samples of Slovenian companies is there are few researchers in the field of accounting in Slovenia.

To date studies from the field of financial accounting indicate that Slovenian SMEs use discretion in accounting standards for tax minimization purposes. Non-tax costs and benefits also seem to be important drivers of their choices. One of the few studies on a sample of Slovenian SMEs was published by Garrod et al. (2008). The work explores economic incentives that drive small private companies operating in Slovenia to record revaluations of current and fixed assets (sample of 23,455 companies). Selected companies are characterized by the absence of agency problem. They find that more profitable companies are more likely to write-off assets and the write-off magnitude is greater. They also find a positive association of company size with the probability to write-off, and negative association with its magnitude. Kosi and Valentinčič (2013) provide further evidence that firms exploit discretion in accounting standards that results in tax savings. Moreover, the results indicate that non-tax costs and benefits are also important drivers when companies choose accounting policies. Their analysis was made on a large sample of 20,505 small private companies.

Mörec (2012) analyzed earnings distribution among Slovenian companies in the period 2008-2010. The results of her analysis shows that earnings shifts occurred more often among micro and small companies in comparison to medium-sized and large companies. The results show statistically significant discontinuity of net earnings' distribution around zero. Micro and small companies that recorded operating loss recognized significantly higher financing income compared to profit making micro and small companies.

Prusnik (2013) studied the link between the tax burden and accounting choice. His sample includes companies of all sizes from the activities of construction, trade and manufacturing. These companies accounted for $51 \%$ of all Slovenian companies. Most of the companies in the sample are micro and small companies. Prusnik (2013) finds that the company's' size (measured by number of employees) affects the propensity of companies to manage profit and thereby to reduce tax liability. Profits are more managed by smaller companies (than large companies) and by companies with a higher effective tax rate. He also notes that companies tend more to manage earnings in times of recession in comparison to times of economic growth. The author also investigated the methods that companies use to manage earnings. $\mathrm{He}$ finds that the amount of tax base and the level of taxation of companies is most often affected by the write-downs of assets and manipulations of purchases and sales, which are reflected in changes of short-term receivables and liabilities. 
At this point it should be useful to summarize the key characteristics of external financial reporting of Slovenian SMEs (Table 3).

Table 3. Key characteristics of external financial reporting of Slovenian SMEs

\begin{tabular}{|c|c|}
\hline Characteristic & Description \\
\hline Legal system & Companies Act provides detailed accounting rules. \\
\hline Accounting standards & $\begin{array}{l}\text { SMEs mostly use the Slovene national standards, exceptions are } \\
\text { consolidated accounts which have to be prepared in line with } \\
\text { IFRS. }\end{array}$ \\
\hline $\begin{array}{l}\text { Frequency of } \\
\text { financial reporting }\end{array}$ & $\begin{array}{l}\text { Annually. The exceptions are companies that are listed in the } \\
\text { security market, which must also prepare interim financial } \\
\text { statements. }\end{array}$ \\
\hline $\begin{array}{l}\text { Publication of annual } \\
\text { reports }\end{array}$ & $\begin{array}{l}\text { Financial reports for external reporting are publicly available at } \\
\text { the website of AJPES. The exception are annual reports of } \\
\text { entrepreneurs who are taxed on the basis of profit, taking into } \\
\text { account flat-rate expenses. They are not obliged to submit annual } \\
\text { reports for publication. }\end{array}$ \\
\hline Tax reports & Mutual influence of taxation and financial accounting. \\
\hline $\begin{array}{l}\text { Preparers of financial } \\
\text { reports }\end{array}$ & $\begin{array}{l}\text { Accounting practitioners are not required to have any } \\
\text { professional qualification nor a professional certificate. } \\
\text { Professional certificates are obtained on a voluntary basis. }\end{array}$ \\
\hline Auditing & $\begin{array}{l}\text { Annual reports of medium-sized companies are audited. } \\
\text { Mandatory audit is not required for annual reports of small } \\
\text { companies (the only exceptions are small publicly listed } \\
\text { companies). New in } 2016 \text { - "preiskava računovodskih izkazov } \\
\text { [examination of financial statements]" of certain small } \\
\text { companies. }\end{array}$ \\
\hline $\begin{array}{l}\text { Harmonization of } \\
\text { national standards } \\
\text { with IFRS }\end{array}$ & $\begin{array}{l}\text { After the latest revision of SAS, the extent of harmonization with } \\
\text { IFRS decreased. }\end{array}$ \\
\hline $\begin{array}{l}\text { Quality of accounting } \\
\text { data }\end{array}$ & $\begin{array}{l}\text { Studies indicate mixed results in terms of firms' size and } \\
\text { accounting discretion. Further evidence is needed. }\end{array}$ \\
\hline $\begin{array}{l}\text { Discretionary } \\
\text { accounting choice }\end{array}$ & $\begin{array}{l}\text { Research indicates that discretion choice in accounting is } \\
\text { motivated by tax minimization reasons. }\end{array}$ \\
\hline
\end{tabular}

\section{Review of research of Slovenian SMEs from the field of management accounting}

Although in the field of management accounting contributions about Slovene SMEs to scientific journals are also limited, the papers from this area of accounting are more numerous and include a quite comprehensive analysis of the development of management accounting among Slovenian companies. The first survey was conducted in 1996 and covered the situation in 1995. The survey was repeated in 2002 (considering the situation at the end of 2001), 2007 and 2008 (addressing the situation at the end of 2006) and 2012 (addressing the situation at the end of 2011) 
(Kavčič et al., 2002; Kavčič et al., 2013). The survey was repeated in order to determine the extent of accounting development and the influence of a variety of socio-economic factors that were present during the analyzed period of time. The study partly covers the area of financial accounting, but is mainly focused on management accounting. The survey was conducted in joint cooperation between the Slovenian Institute of Auditors, the Association of Accountants, Treasurers and Auditors of Slovenia and the Faculty of Economics, University of Ljubljana (Kavčič et al., 2002; Kavčič et al., 2013).

The questionnaire consisted of 133 questions, divided into several themes. Research was repeated using the same methodology; therefore, the results of the study are comparable. The researchers excluded from the analysis companies with a number of employees lower than 20 . They assumed that in the majority of micro-enterprises accounting is narrowed to bookkeeping, and thus most companies of this kind could not answer a number of the survey questions (Kavčič et al., 2013).

The questionnaire included in addition to some general questions about the company questions about the organization of accounting, methods of valuation of economic categories, information provided for decision-making, information for the purpose of performance measurement analysis and areas of responsibility (Kavčič et al., 2013). In 1995, this was the first comprehensive study in the field of accounting since Slovenia became independent. None yet has been more comprehensive. Table 4 presents the number of companies included in the survey and the number of companies obliged to prepare annual reports for whole period of their analysis.

Table 4. Number of companies included in the survey and the number of companies obliged to prepare annual reports

\begin{tabular}{lcccc}
\hline & $\mathbf{1 9 9 5}$ & $\mathbf{2 0 0 1}$ & $\mathbf{2 0 0 6}$ & $\mathbf{2 0 1 1}$ \\
\hline Companies in the survey & 286 & 320 & 173 & 161 \\
Companies obliged to prepare annual reports & 33,609 & 37,210 & 45,330 & 57,798 \\
\hline \multicolumn{4}{c}{ Source: Kavčič et al. $(2013)$} \\
\end{tabular}

As can be noticed, the number of respondents decreased over time, since companies are not willing to fulfill long questionnaires. Nowadays companies can hardly devote time to answering the questionnaires of this kind. In the first two surveys $10 \%$ of the sample was represented by small enterprises, in $200630 \%$, and in $201134 \%$. In the case of medium-sized enterprises the proportion ranged from $30 \%$ to $34 \%$. In 2001 , the share of large enterprises was the largest, amounting to 59\%. In 2006 and 2011 it fell to 36\% (Odar et al., 2009; Kavčič et al., 2013).

Their data show that the accounting department has gained in importance. Companies where the accounting department represents a predominant source of information for decision making amounted to $49 \%$ in 1995 and rose to 64\% in 2011 (Kavčič et al., 2013; Kavčič et al., 2014). 
In 1995 , only $60 \%$ of companies prepared different information for different levels of decision-making. The results do not differ significantly by firm size (Kavčič et al., 1998). In 2011, the situation had improved, yet the percentage was still only $68 \%$ (Kavčič et al., 2014). These data show that the management accounting system in Slovenia is not highly developed. As suggested by the theory we would expect that different hierarchical levels of decision-makers would receive information appropriate to specific needs (for details see Gorry \& Scott Morton, 1971).

Among the companies there are substantial differences between the information that the accounting department provides on a daily, weekly and monthly basis to management (Kavčič et al., 2003; Kavčič et al., 2010; Kavčič et al., 2014; Odar et al., 2015). Kavčič et al. (2014) found that the information most frequently reported to management is about liquidity. The authors found that the extent of information that the accounting department provides to management increased, especially in the period of crisis (Kavčič et al., 2014; Odar et al., 2015). In times of crisis, compared to the year 2006, management was willing to receive more information about cash and liquidity (Odar et al., 2015).

The most interesting findings of the survey as regards information about specific basic business functions are (Kavčič et al., 2004a; Kavčič et al., 2004b; Kavčič et al., 2013):

- Budgeted balance sheet was prepared by 47\% of companies in 1995, by 2011 the share rose to $70 \%$, indicating a significant improvement.

- The budgeted cash flow statement was prepared by $66 \%$ of the companies in 2006, in 2011 the share increased to $77 \%$.

- Before 2006 accounting departments only rarely made budgets or monitored their deviations.

- In $1995,35 \%$ of enterprises had no responsibility centers, $48 \%$ in $2011 \%$. Data show that the decentralization of decision-making in Slovenian medium-sized and small companies is relatively rare. Among those companies that have responsibility center(s), the majority established cost centers of responsibility.

Within the survey, the authors asked about the form of income statement used by the respondents. The most commonly used method of income statement is that which classifies the expenses on a natural basis. Its importance in time increased from $75 \%$ in 1995 to $80 \%$ in 2011 (Kavčič et al., 2013). SAS suggests the use of an income statement that classifies expenses on a functional basis, but both are permitted.

Odar et al. (2012) analyzed in detail the performance measurement systems used by large, medium and small Slovenian companies. Their analysis was made on a sample of 167 companies, of which $36.5 \%$ are large companies, $33.5 \%$ medium, and $30 \%$ small-sized companies. They found that Slovenian companies predominately use traditional performance measurement techniques, while contemporary techniques are used rarely. The research further explored the use of different groups of ratios 
which were defined by the SAS 2006. The analysis reveals no statistically significant difference in their use between companies of different size in the case of leverage ratios, while it shows statistically significant difference in the case of liquidity and turnover ratios. Smaller companies use fewer ratios than larger companies. The authors found that the majority of small companies from the sample (64\%) for performance evaluation purposes use comparison of the current results with the previous years' results and plan. Odar et al. (2012) found that economic performance measurement methods (like EVA) are used only rarely. They performed an additional test, analyzing whether there are significant differences between those companies that have an internal accounting department and those which use external providers of accounting services. Authors could not find significant differences between these two groups. Their findings also suggest that accounting practitioners in small companies perform bookkeeping activities almost exclusively. Their study confirms findings of Haldma and Lääts (2002) and Hopper et al. (2009) which have shown that transitional and less developed economies have management accounting systems that are less developed than those in traditional market economies.

The results of these comprehensive studies over a period of 16 years provide important information about the development of accounting in Slovenia. Unfortunately, the research does not consider micro companies, a significant share of Slovenian companies. As Kavčič et al. (2013) points out, the majority of micro organizations narrow accounting to bookkeeping.

The surveys from the field of management accounting in Slovenia show that solutions from developed market economies were quickly introduced at the level of theory. However, a gap has emerged between theory and practice (Milost, 1998; Kavčič et al., 2013).

\section{Conclusions}

We find that the majority of small and micro-enterprises (representing almost $99 \%$ of total Slovene enterprises) compile only a balance sheet and income statement for external reporting purposes. Approximately a third of sole traders (which represent almost a half of all enterprises in Slovenia) do not submit annual reports for publication, because they have the option not to do so if they are taxed using the system of flat-rate expenses. Since 2015, when the legislature increased the proportion of normalized expenses, the number of enterprises which have opted for this type of taxation (and therefore those that do not submit annual reports for publication) increased. We expect that their number will increase in the future as well.

In accordance with the fact that accounting professionals in Slovenia are not required to have any professional certificate and that the supervision of financial statements in the case of most small and micro-enterprises is rather limited, the tax authority (as 
an indirect general enforcement authority for accounting standards), should consider increasing the number of tax inspectors, which currently number relatively few.

SAS 2016 no longer refers to IFRS. SAS are now completely independent standards. Although the Slovenian Companies Act states that SAS shall not be contrary to IFRS, there are certain differences between them. After the latest revision of SAS, the extent of harmonization with IFRS actually decreased. We expect that the extent of differences between SAS and IFRS will increase in time, as the frequency of IFRS changes is greater than those of SAS. The latest version of SAS was introduced 10 years after the preceding one. Therefore, the legislature should eliminate the provision from the Companies Act requiring that the SAS must not be contrary to the IFRS.

We found that since the EU Directive 2013/34 was implemented into Slovenian law, corporate reporting of small and especially micro enterprises was simplified. We believe that future changes of SAS will be also tailored toward further simplifications of accounting for SMEs.

Studies from the field of financial accounting in Slovenia reviewed here were mainly focused on the linkage between financial accounting and taxation. The use of accounting discretion is motivated by the effort to minimize taxation. Studies indicate mixed results in terms of firms' size and accounting discretion. Further evidence is needed.

The literature review from the field of SMEs in Slovenia shows that there are numerous possibilities for further research. Studies of small, especially micro, companies are few. More studies are needed to investigate the quality of accounting data prepared for the purpose of external financial reporting. To date, there remains a lack of research investigating whether the application of revised versions of national accounting standards are associated with increased quality of accounting information. This issue is important, since most of the SMEs report in accordance with SAS.

In the field of management accounting possibilities for future studies are numerous. Studies could focus on cost allocation processes in use, approaches to budgeting, management control systems design and performance measurement systems. To date little is known especially in regard to the micro enterprises that are so numerous in Slovenia. We have shown that in Slovenia there are relatively numerous external accounting service providers, which assist small and micro-companies almost exclusively. Future studies could investigate the extent of management accounting information prepared by these kinds of organizations. Thus, more research is needed both from the field of financial and management accounting. SAS is in a large part in conformity with IFRS, thus the Slovenian environment has integrated contemporary accounting solutions. 


\section{References}

AJPES (Agency of the Republic of Slovenia for Public Legal Records and Related Services) (2016) "Public Posting of Annual Reports", available online at https://www.ajpes.si/jolp/ (on-line access: November $23^{\text {rd }}$ 2016)

Auditing Act (Zakon o revidiranju) (2008), available online at http://www.pisrs.si/Pis.web/pregledPredpisa?id=ZAKO5273 (on-line access: March 19 $9^{\text {th }}$ 2017)

Chamber of Commerce and Industry of Slovenia (2016) "Development and representation of NACE 69.200 for 2015", available online at https://www.gzs.si/zbornica_racunovodskih_servisov/vsebina/Zapodjetja/Prikaz-dejavnosti/Razvoj-in-\%C5\%A1tevil\%C4\%8Dni-prikazpanoge-2015 (on-line access: December $3^{\text {rd }} 2016$ )

Companies Act (Zakon o gospodarskih družbah) (2006), available online at http://www.pisrs.si/Pis.web/pregledPredpisa?id=ZAKO4291 (on-line access: November $24^{\text {th }} 2016$ )

Corporate Income Tax Act (Zakon o davku od dohodkov pravnih oseb - ZDDPO-2) (2006), available online at http://www.pisrs.si/Pis.web/pregledPredpisa?id=ZAKO4687 (on-line access: November $24^{\text {th }} 2016$ )

Delo (2016) "Flat tax displaces other forms of work", available online at http://www.delo.si/gospodarstvo/finance/pavsalna-obdavcitev-izriva-drugeoblike-dela.html (March 21 ${ }^{\text {st }} 2017$ )

Garrod, N. \& Turk, I. (1995) "The development of accounting regulation in Slovenia", The European Accounting Review, vol. 4, no. 4: 749-764

Garrod, N., Kosi, U. \& Valentinčič, A. (2008) "Asset Write-Offs in the Absence of Agency Problems", Journal of Business Finance \& Accounting, vol. 35, no. 3-4: $307-330$

Gorry, G.A. \& Scott Morton, M.S. (1971) "A Framework for Management Information Systems", Sloan Management Review, vol. 13, no. 1: 55-70

GVIN (Financial data) (2017), available online at http://www.bisnode.si/ produkt/gvin/ (on-line access: January $6^{\text {th }}$ 2017)

Haldma, T. \& Lääts, K. (2002) "Contingencies influencing the management accounting practices in Estonian manufacturing companies", Management Accounting Research, vol. 13, no. 4: 379-400

Haller, A. \& Walton, P. (2003) "Country differences and harmonization?", in P. Walton, A. Haller \& B. Raffournier (Eds.), International Accounting, pp. 1-34), London: Thomson

Hopper, T., Tsamenyi, M., Uddin, S. \& Wickramasinghe, D. (2009) "Management accounting in less developed countries: what is known and what needs knowing", Accounting, Auditing \& Accountability Journal, vol. 22, no. 3: 469-514

Jerman, M. \& Novak, A. (2014) "IFRS application in Slovenia", Accounting and Management Information Systems, vol. 13, no. 2: 351-372 
Kavčič, S., Koželj, S. \& Odar, M. (2004a) "Development of Management Accounting in Slovene Companies", Revizor [Auditor], vol. 15, no. 2: 54-95

Kavčič, S., Koželj, S. \& Odar, M. (2004b) "Development of Management Accounting in Slovene Companies", Revizor [Auditor], vol. 15, no. 3: 26-63

Kavčič, S., Koželj, S. \& Odar, M. (2010) "Development of accounting in Slovene companies", Revizor [Auditor], vol. 21, no. 2: 29-64

Kavčič, S., Koželj, S. \& Odar, M. (1998) "Development of accounting in Slovenian companies", Revizor [Auditor], vol. 9, no. 3: 40-57

Kavčič, S., Koželj, S. \& Odar, M. (2002) "Development of accounting in Slovene companies: first findings of research by the Slovenian Institute of auditors and the Faculty of Economics of the University of Ljubljana”, Revizor [Auditor], vol. 13 , no. 11: $71-87$

Kavčič, S., Koželj, S. \& Odar, M. (2003) "State of development of management accounting in Slovene companies", Revizor [Auditor], vol. 14, no. 11: 58-87

Kavčič, S., Odar, M. \& Koželj, S. (2013) "Development of accounting in Slovenian companies - presentation and first research results", Sirius, vol. 1, no. 6: $110-134$

Kavčič, S., Odar, M. \& Koželj, S. (2014) "Development of Management Accounting in Slovene Companies - Information for the first and the second decisionmaking levels", Sirius, vol. 2, no. 5: 117-143

Kosi, U. \& Valentinčič, A. (2013) "Write-offs and Profitability in Private Firms: Disentangling the Impact of Tax-Minimisation Incentives", European Accounting Review, vol. 22, no. 1: 117-150

Milost, F. (1998) "Development of accounting theories", Revizor [Auditor], vol. 9, no. 2: $50-59$

Ministry of Public Administration (2016) "Annual report of the Inspection Board for the year 2015", http://www.mju.gov.si/fileadmin/mju.gov.si/pageuploads/

JAVNA_UPRAVA/SOUS/mnenja/Letno_porocilo_Inspekcijskega_sveta_za_leto_ 2015.pdf (January $12^{\text {th }}$ 2017)

Mörec, B. (2012) "Do small companies have superior financial expertise or are they just managing earnings?", International Business \& Economics Research Journal, vol. 11, no. 12: 1289-1298

Novak, A. (2008) "Harmonization of Slovene accounting standards with International financial reporting standards", in Kandžija, V., Kumar, A. (eds.) 50 years of European Union $=$ L'Union Éuropéenne a 50 ans: research monograph. Rijeka: University of Rijeka, Faculty of Economics: 511-520

Novak, A. \& Valentinčič, A. (2017). "The Role and Current Status of IFRS in the Completion of National Accounting Rules - Evidence from Slovenia", Accounting in Europe, vol. 14, no. 1-2, 187-198

Odar, M., Kavčič, S. \& Jerman, M. (2012) "Performance measurement systems: empirical evidence from Slovenia", Economic Research, vol. 25, no. 2: 445-464

Odar, M., Kavčič, S. \& Jerman, M. (2015) "The role of a management accounting system in the decision-making process: evidence from a post-transition economy", Engineering Economics, vol. 26, no. 1: 84-92 
Odar, M., Kavčič, S. \& Koželj, S. (2009) "Organisation of accounting in Slovene companies", Revizor [Auditor], vol. 20, no. 4: 63-81

Personal Income Tax Act (Zakon o dohodnini-ZDoh-2) (2006), available online at http://www.pisrs.si/Pis.web/pregledPredpisa?id=ZAKO4697 (November $25^{\text {th }}$ 2016)

Prusnik, M. (2013) "Correlation between tax burden and accounting choice: Slovenian example, $\mathrm{PhD}$ Thesis", available online at http://www.cek.ef.unilj.si/doktor/prusnik.pdf (January $16^{\text {th }} 2016$ )

SAS 2006 (Slovene Accounting Standards 2006) (2006) Ljubljana: Association of Accountants, Treasurers and Auditors of Slovenia

SAS 2016 (Slovene Accounting Standards 2016) (2016) Ljubljana: The Slovenian Institute of Auditors

SI-STAT (2016) "Enterprises by industry (SKD 2008) and their size, Slovenia", available online at letnohttp://pxweb.stat.si/pxweb/Database/Ekonomsko/14_poslovni_subjekti/ 01_14188_podjetja/01_14188_podjetja.asp (December $7^{\text {th }}$ 2016)

Slapničar, S., Zaman Grof, M. \& Štumberger, N. (2013) "Does professional accounting qualification matter for the provision of accounting services?" In C. N. Albu \& R. V. Mustata (Eds.), Accounting in Central and Eastern Europe (pp. 255-277), Bingley: Emerald Group Publishing Limited

SORS (Statistical Office of the Republic of Slovenia) (2016) "Enterprises, Slovenia, 2015", available online at http://www.stat.si/StatWeb/prikazi-novico ?id $=6328 \&$ idp $=16 \&$ headerbar $=14\left(\right.$ December $\left.7^{\text {th }} 2016\right)$

The Slovenian Institute of Auditors (2016) "List of auditing firms", available online at http://sis.si-revizija.si/public/registry/revcompanylist (December $11^{\text {th }} 2016$ ) 